\title{
ROLE OF SERUM ASSISTED CONJUNCTIVAL AUTOGRAFT IN THE MANAGEMENT OF PRIMARY PTERYGIUM
}

\author{
S. Mishra ${ }^{1}$, B. Mayuri², Debabrata Panigrahi ${ }^{3}$ \\ ${ }^{1}$ Senior Consultant, Department of Cornea and Microsurgery, JPM Rotary Club of Cuttack Eye Hospital and Research Institute, Odisha. \\ ${ }^{2} D N B$ Trainee, JPM Rotary Club of Cuttack Eye Hospital and Research Institute, Odisha. \\ 3Professor, Department of ENT, IMS and SUM Hospital, Bhubaneswar, Odisha.
}

\section{ABSTRACT}

\section{BACKGROUND}

Objective- To evaluate the outcome of serum assisted conjunctival autograft in patients with primary pterygium.

\section{MATERIALS AND METHODS}

An uncontrolled clinical trial was done over a period of 18 months, where 86 cases of primary pterygium of different age group had undergone excision of the pterygium followed by conjunctival autografting without suturing and without application of glue. Patient's owned serum was utilised as the bioadhesive material for stability of the graft. All the cases were followed up for 6 months. The recurrence rates, graft stability, improvement of visual acuity and presence or absence of untoward symptoms that are common in suturing or glue application were observed.

\section{RESULTS}

Successful outcome with stable graft observed in $89.5 \%$ of the cases and the recurrence, which is the most common long-term complication of the pterygium surgery was noticed only in $2.3 \%$ of cases after 6 months followup period. Visual acuity improvement was observed in $15 \%$ of cases and the untoward symptoms like foreign body sensation, watering and pain were completely absent in this technique.

\section{CONCLUSION}

Serum assisted conjunctival autografting is a safe and effective method of treatment for primary pterygium with a high success rate. The recurrence rate is minimum and the visual acuity improvement occurs in a quite significant number of cases. Suture related complications and the glue associated risks can be avoided by this technique. As this method is cost effective with an easy learning curve, this can be considered as valid alternative to other methods.

\section{KEYWORDS}

Pterygium Surgery, Primary Pterygium, Serum Assisted Conjunctival Autografting.

HOW TO CITE THIS ARTICLE: Mishra S, Mayuri B, Panigrahi D. Role of serum assisted conjunctival autograft in the management of primary pterygium. J. Evolution Med. Dent. Sci. 2017;6(43):3371-3375, DOI: 10.14260/Jemds/2017/730

\section{BACKGROUND \\ Pterygium is an elastotic degeneration of the subconjunctival tissue, which proliferates as vascularised granulation tissue to encroach on to the cornea destroying the superficial layers of the stroma and Bowman's membrane. ${ }^{1}$ It usually occurs in the interpalpebral fissure and most often involves the nasal side. \\ This lesion commonly affects people with more exposure to sunlight. ${ }^{2}$ Prevalence rate up to $22 \%$ has been reported in countries having geographical location of $40^{\circ}$ latitude to either side of the equator. 1,3 \\ Early pterygiums are usually asymptomatic. As the disease progresses symptoms like burning sensation, watering and foreign body sensation appears. When the disease extends on to the cornea, it can cause defective vision either due to direct involvement of the visual axis or due to induced astigmatism.}

Financial or Other, Competing Interest: None.

Submission 21-04-2017, Peer Review 15-05-2017,

Acceptance 22-05-2017, Published 29-05-2017.

Corresponding Author:

Dr. Debabrata Panigrahi.

Department of ENT,

IMS \& SUM Hospital,

K8. Kalinga Nagar, Ghatikia,

Bhubaneswar-751003, Odisha.

E-mail:drdbpent@gmail.com

DOI: $10.14260 /$ jemds $/ 2017 / 730$
Many surgical procedures have been proposed for the management of pterygium. Starting from simple bare sclera excision to more complex surgeries like lamellar keratoplasty and amniotic membrane transplantations has been tried to minimise the recurrence rate and complications. Recurrence rates reported in literature varies widely from $0 \%$ to $89 \% .4,5$ Conjunctival autograft is considered as the gold standard for pterygium surgery in terms of efficacy and safety. ${ }^{6}$ Suturing the conjunctival autograft is the standard method followed in this surgery. But the suture related complications like infections, granuloma formation, chronic inflammation, symblepharon formation, ocular motility restriction, diplopia and scleral necrosis are the disadvantages of this method. 6

Though, the use of fibrin glue has already become popular to avoid suturing and its complications, but potential risk of prion disease transmission and anaphylaxis in susceptible individuals are its major limitations. Fibrin glue is also expensive compared to sutures.

To overcome these complications, serum-assisted conjunctival autograft has been introduced where patient's own blood is used as a bio-adhesive material. ${ }^{7}$ The naturally occurring fibrin in the serum helps to adhere the graft. This is cost effective and avoids the complication of the suture.

This study is undertaken to evaluate the efficacy of this new method in terms of graft stability, visual acuity and complications. 


\section{Aims and Objectives}

1. To evaluate the outcome of serum assisted conjunctival autograft in primary pterygium surgery.

2. To report any associated complications and recurrence rates of this technique.

\section{Sample Size with Justification}

The objective of the study is to assess the outcome of serum assisted conjunctival autograft in primary pterygium cases. The outcomes are evaluated in terms of graft stability, graft displacement and loss and the rate of recurrence and complications. The review of literature states that the rate of non-recurrence and graft stability is in and around $90 \%$. The study design assumed that the true rate of outcomes is about $10 \%$ in and around $90 \%$. Under this condition, the minimum sample size determination was computed for hypotheses test for a population proportion for two-sided tests.

The relevant formula for minimum sample size:

$$
\mathrm{n}=\left\{Z_{1-\alpha / 2} \llbracket \sqrt{\left.\left[P_{0}\left(1-P_{0}\right)\right] \rrbracket+Z_{1-\beta} \llbracket \sqrt{\left[P_{a}\left(1-P_{a}\right)\right]}\right\}^{2} /\left(P_{0}-P_{a}\right)^{2}}\right.
$$

\section{Following Parameters are considered for the Purpose}

1. Level of Significance $=5 \%$

2. Power of the Test $=80 \%$

3. $\mathrm{P}_{\mathrm{o}}=90 \%$ (Success rate from previous literature)

4. $\mathrm{Pa}=80 \%$ or $100 \%$ (Anticipated success rate that somewhere lies between $10 \%$ point around $90 \%$ )

5. Alternative hypothesis- Two-sided test, i.e. success rate $\neq$ $90 \%$

Under the above conditions, the minimum sample size is determined to be 86 .

Reference: Lwanga S. K. and Lemeshow S.

"Sample Size Determination for Health Studies- A Practical Manual, World Health Organisation, 1991."

\section{Data Analysis}

In order to fulfil the objectives of the study data on age, gender, occupation, laterality, grading of pterygium, preoperative and postoperative BCVA, postoperative symptoms and signs, outcome of the graft etc. were statistically analysed in SPSS 16.0 software. Analysis along with interpretations is presented on observation and discussion. Demographic profile like age, sex and occupation of the patients was done using frequency procedure in SPSS. The preponderance of distribution of sex and occupation was tested using binomial test for the test proportion of .50 .

\section{MATERIALS AND METHODS}

An uncontrolled clinical trial was done with due ethical clearance on 86 patients of grade- 1 and grade- 2 primary nasal pterygium at JPM Rotary Club of Cuttack Eye Hospital and Research Institute over a period of 18 months from June 2014 to December 2015.

Grade 3, temporal, double-headed and recurrent pterygium cases were excluded from the study group. Similarly, pterygium with total limbal stem cell deficiency, with Ocular Surface Squamous Neoplasia (OSSN) and with impacted intraocular foreign body were also excluded from the study.
Patients having associated problems like dry eyes, symblepharon, conjunctivitis and keratitis were also not included in the study group.

All the selected cases had undergone pterygium excision with serum assisted conjunctival autograft transplantations and followup observations was done for 6 months. Followup examination was done on the first day, the first week, first month and 6 months. The outcome of the surgery was measured by graft stability, recurrence of the disease, complications and presence or absence of symptoms like foreign body sensations and watering. The observed data were statistically analysed in SPSS 16.0 Software.

\section{Surgical Technique}

All the surgeries were performed by the first author to ensure similarity in the procedure, thereby eliminating intersurgeon variability. Peribulbar anaesthesia with $2 \%$ lignocaine and $0.5 \%$ bupivacaine in 1:1 ratio was given preoperatively. All the cases were operated under microscope. The body of the pterygium along with the underlying Tenon's was excised using Westcott scissors. Large haemorrhages were tamponade with direct compression. The area of the conjunctival defect was measured with Castroviejo calipers and a free conjunctival autograft of around $0.5-1 \mathrm{~mm}$ oversize was obtained from the superotemporal quadrant of the bulbar conjunctiva (Fig. 1). Meticulous dissection was performed to remove most of the tenon's tissue in the autograft. A thin film of blood clot was allowed to form over the bare sclera. The graft was put over the conjunctival defect with proper orientation to maintain the limbus to limbus and stromal side facing downward. The graft was kept apposed to the scleral bed for 5 minutes by applying gentle pressure with fine non-toothed forceps (Fig. 2). The eye was bandaged for 24 hours. The bandage was opened on the first postoperative day. Post-operatively, topical steroids, antibiotics, tear substitutes were administered. Followup was done on day 1, $1^{\text {st }}$ week, 1st month and 6 months (Fig. 3, Fig. 4).

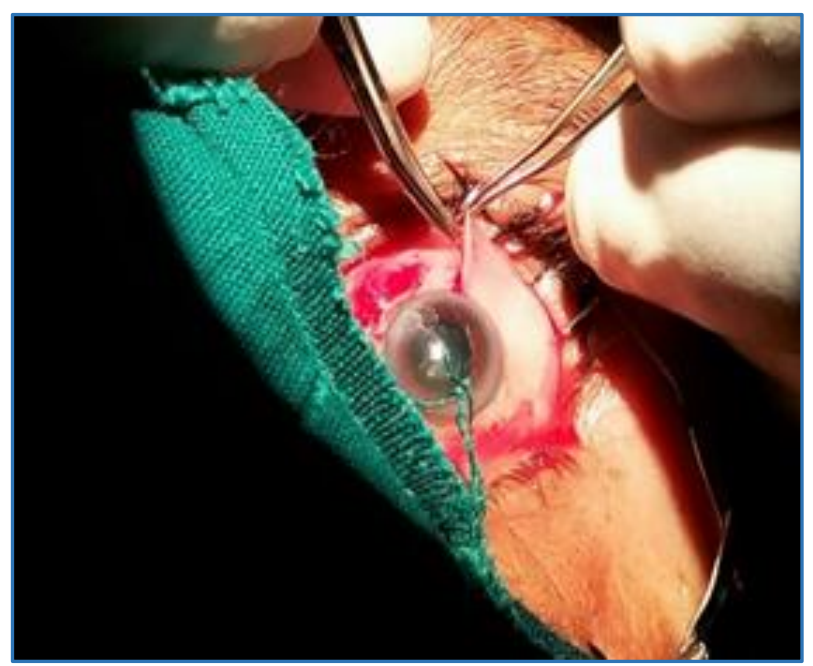

Figure 1. Harvesting Autograft from Sup. Bulbar Conjunctiva 


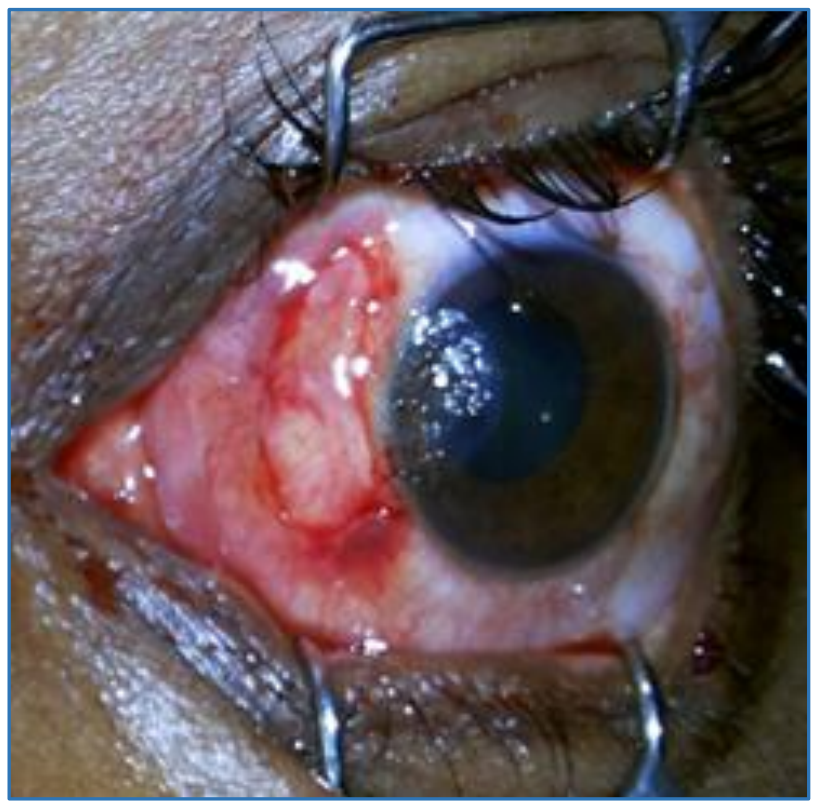

Figure 2. Graft kept Apposed to Scleral Bed for 5 Minutes

\section{RESULTS}

A total of 86 patients with 86 eyes were included in the study. Out of these 86 cases, 64 (74.4\%) were males and 22 (25.6\%) were females. Maximum proportion of cases belonged to 40 60 years of age $(53.5 \%)$ followed by $20-40$ years $(33.7 \%)$ with mean age of the patient found to be 45.86 years. People with outdoor occupation having more exposure to sunlight contributed to majority of cases $(81.4 \%)$.
Out of the total 86 cases preoperatively, 67 patients $(77.9 \%)$ were having visual acuity of $6 / 12-6 / 6$, whereas after 6 months of surgery 80 patients $(93 \%)$ were found to have visual acuity of $6 / 12-6 / 6$, which shows an improvement of visual acuity in $15 \%$ of cases (Table 1 ).

\begin{tabular}{|c|c|c|c|c|}
\hline $\begin{array}{c}\text { Visual Acuity } \\
\text { (BCVA) }\end{array}$ & $\begin{array}{c}\text { Pre- } \\
\text { operative } \\
\text { Cases }\end{array}$ & $\begin{array}{c}\text { Pre- } \\
\text { Op.\% }\end{array}$ & $\begin{array}{c}\text { 6 Month } \\
\text { Post- } \\
\text { Operative } \\
\text { Cases }\end{array}$ & $\begin{array}{c}\text { Post-0p } \\
\% .\end{array}$ \\
\hline $6 / 60$ & 0 & & 0 & \\
\hline $6 / 60-6 / 24$ & 12 & $14 \%$ & 3 & $3.5 \%$ \\
\hline $6 / 24-6 / 12$ & 7 & $8 \%$ & 3 & $3.5 \%$ \\
\hline $6 / 12-6 / 6$ & 67 & $77.9 \%$ & 80 & $93 \%$ \\
\hline Table 1. (n = 86): Visual Acuity Pre- and Post-Operative \\
Evaluation \\
\hline
\end{tabular}

On evaluation of graft stability, it has been observed that overriding of graft on cornea due to slightly oversized graft was present in 5 cases (5.8\%) on $1^{\text {st }}$ postop day, which was immediately addressed by trimming and repositioning in 3 cases and by suturing in 2 cases. Similarly, another 5 cases (5.8\%) found to have gaping on $1^{\text {st }}$ postop day due to undersized graft, which was also managed by suturing. Keeping aside the 7 cases managed by suturing, the remaining 79 cases were found to have excellent graft take up in subsequent followup visits, i.e. $1^{\text {st }}$ week, $1^{\text {st }}$ month and 6 months. (Fig. 3 and 4) Not a single case of graft loss was observed in this case series. So, the success rate of graft stability in this case study is 79 out of 86 cases, i.e. $91.8 \%$ (Table 2).

\begin{tabular}{|c|c|c|c|c|c|c|c|c|}
\hline $\begin{array}{c}\text { Followup } \\
\text { Period }\end{array}$ & $\begin{array}{c}\text { Graft } \\
\text { Loss }\end{array}$ & $\begin{array}{c}\text { Over-Riding } \\
\text { on Cornea }\end{array}$ & $\begin{array}{c}\text { Gaping and } \\
\text { Retraction }\end{array}$ & $\begin{array}{c}\text { Cases } \\
\text { Required } \\
\text { Suturing }\end{array}$ & $\begin{array}{c}\text { Stable Graft } \\
\text { without } \\
\text { Suturing }\end{array}$ & Recurrence & $\begin{array}{c}\text { Successful } \\
\text { Outcome }\end{array}$ & $\begin{array}{c}\text { \% of Successful } \\
\text { Outcome }\end{array}$ \\
\hline $1^{\text {st }}$ Day & 0 & 5 & 5 & 7 & 76 & NA & 76 & $88.4 \%$ \\
\hline $1^{\text {st }}$ Week & 0 & 0 & 0 & 7 & 79 & 0 & 79 & $91.8 \%$ \\
\hline $1^{\text {st } \text { Month }}$ & 0 & 0 & 0 & 7 & 79 & 0 & 79 & $91.8 \%$ \\
\hline 6 Months & 0 & 0 & 0 & 7 & 79 & 2 & 77 & $89.5 \%$ \\
\hline \multicolumn{7}{|c|}{ Table 2. (n= 86), Successful Outcome at each Followup Period } \\
\hline
\end{tabular}

On $1^{\text {st }}$ postoperative day, symptoms and signs like foreign body sensation, watering, chemosis and pain which are considered to be very troublesome for patients with suturing method were not present in a single case in this case series. On subsequent followup visits in $1^{\text {st }}$ week, $1^{\text {st }}$ month and 6 months, besides cases which required suturing on $1^{\text {st }}$ postop day, the other 79 cases were free from any signs and symptoms.

Recurrence of the disease has been noticed in only 2 cases (2.5\%) out of 79 cases. Considering the complications in 7 cases which required suturing subsequently and recurrence of pterygium in 2 cases, the total successful outcome observed was 77 out of 86 cases, i.e. $89.5 \%$ (Table 2).

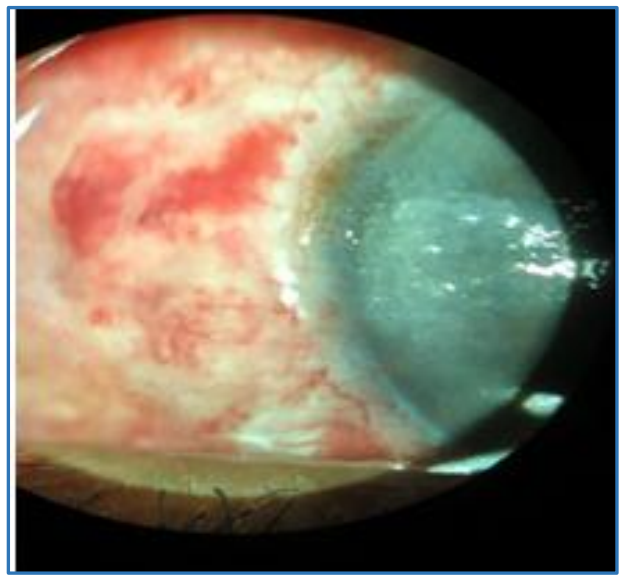

Figure 3. Graft Stability, 1st Week Post-Op 


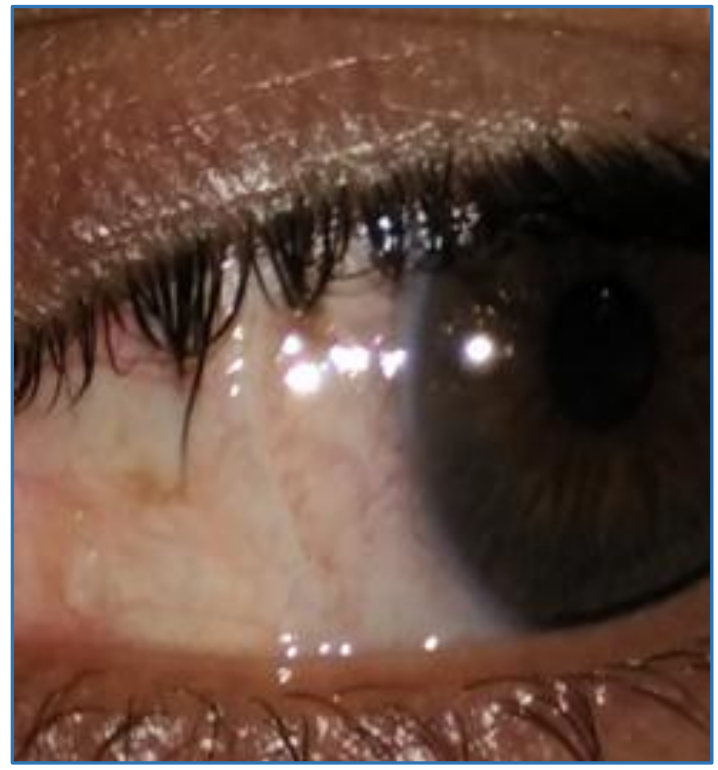

Figure 4. Graft Stability, $1^{\text {st }}$ Month Post-Op

\section{DISCUSSION}

In this case series, male preponderance of the disease was noticed which was similar to the studies of Rangu RV et al (2014), ${ }^{8}$ Morya AK et al $(2015)^{9}$ and Kulthe SB et al (2015). ${ }^{10}$ The mean age of the patient in the study was 45.86 years. Malik KPS et al (2012) ${ }^{11}$ and Rathi G et al (2015) ${ }^{12}$ in their respective studies found mean age of the patients as 42.8 years and 42.5 years respectively. Rangu RV et al $(2014)^{8}$ also in their study on sutureless and glue-free conjunctival autograft reported the mean age of the patient to be 52.4 years. As the people in this age group are active and work outdoors, they get more exposure to sunlight which might be the cause for increased prevalence of the disease in this age group.

People with outdoor occupation consists of $81.4 \%$ of patients in this series, which correspond to the study by Moran DJ et al ${ }^{13}$ indicating people working outdoors are the common victims of this disease.

Visual acuity improvement has been observed in 15\% of cases in this series (Table 1). D De Wit et al ${ }^{14}$ and Elwan SAM 15 in their study reported improvement of visual acuity in $6.7 \%$ and $8.0 \%$ of cases respectively. Postoperative visual acuity improvement was quite significant in the study compared to others.

In this case series, graft displacement was noticed in 10 cases $(11.6 \%)$ on $1^{\text {st }}$ postoperative day. Sangole $\mathrm{M}$ et $\mathrm{al}^{16}$ made a similar observation of graft displacement in $18.8 \%$ cases on $1^{\text {st }}$ postoperative day. Singh PK et al ${ }^{17}$ noticed displacement in 1 out of 10 cases (10\%). Many other reported series noticed even less displacement than the present study like Rathi $\mathrm{G}$ et $\mathrm{al}_{12}(2 \%)$, Kulthe SB et al ${ }^{10}$ (3.7\%) and D de Wit et al ${ }^{14}(0 \%)$. A total percentage of graft stability noticed in the present series was $91.8 \%$, which was similar to the observation done by Malik KPS et al (2012) ${ }^{11}$ (87.5\%), Rathi G et al ${ }^{12}$ (98\%) and Kulthe SB et al ${ }^{10}$ (96.2\%).

No troublesome symptoms like pain, watering and foreign body sensation were noticed in the present study on $1^{\text {st }}$ postoperative day. Besides cases which required suturing for stabilising the graft on $1^{\text {st }}$ post-operative day, other cases exhibited absolute quietness on subsequent followup also. Sharma et al $^{18}$ noticed symptoms in $20 \%$ of cases, Sangole et $\mathrm{al}^{16}$ in $34.4 \%$ of cases and D de Wit et al ${ }^{14}$ in $20 \%$ of cases. The comfort level of patients was excellent in this study compared to others.

Recurrence noticed in 2 cases (2.3\%) in this study at 6 months followup, which is comparable to the observation made By Malik KPS et al (2012) ${ }^{11}(2.5 \%)$, Rathi G et al ${ }^{12}(2 \%)$ and Elwan Sam ${ }^{15}(6 \%)$. Quite a few studies like Rangu RV et al (2014), ${ }^{8}$ Kulthe SB et al,10 Sharma A et al ${ }^{18}$ and D de Wit et $\mathrm{l}^{14}$ observed even zero recurrence rate in their respective studies.

Overall success rate in this case series at 6 months followup was found to be $89.5 \%$ (Table 2). Malik KP et $\mathrm{al}^{11}$ noticed successful outcome in $85 \%$ of cases and Rangu RV et $\mathrm{al}^{8}$ in $75 \%$ of cases at 12 months followup period. Rathi G et al $^{12}$ observed successful outcome over 6 months followup period, even in $92 \%$ of cases.

\section{CONCLUSION}

Serum assisted conjunctival autograft is a better alternative to autograft either with suturing or with glue. This procedure is cost effective, cosmetically better and post-operative comfort level is excellent with minimum signs and symptoms. The recurrence rate, which is the most common long-term complication of the pterygium surgery, is minimum in this technique and the visual acuity improvement occurs in quite a significant number of cases. The potential risk associated with use of fibrin glue and suture related complications can be avoided by this method. So, it is safe, effective and economical method for management of primary pterygium with minimum recurrence rate compared to other techniques.

\section{REFERENCES}

[1] Duke-Elder S, Leigh AG. Diseases of the outer eye. In: System of ophthalmology. Vol: 8. London: Henry Kimpton publ 1965:573-85.

[2] MacKenzie FD, Hirst LW, Battistuta D, et al. Risk analysis in the development of pterygia. Ophthalmology 1992;99(7):1056-61.

[3] Hilgers JH. Pterygium: its incidence, heredity and etiology. Am J Ophthalmol 1960;50:635-44.

[4] Snibson GR, Luu CD, Taylor HR. Pterygium surgery in Victoria: a survey of ophthalmologist. Aust NZ J Ophthalmol 1998; 26 (4):271-6.

[5] Mutlu FM, Sobaci G, Tatar T, et al. A comparative study of recurrent pterygium surgery: limbal conjunctival autograft transplantation versus mitomycin $\mathrm{C}$ with conjunctival flap. Ophthalmology 1999; 106 (4): 817-21.

[6] Allan BD, Short P, Crawford GJ, et al. Pterygium excision with conjunctival autografting: an effective and safe technique. Br J Ophthalmol 1993; 77 (11): 698-701.

[7] Koranyi G, Seregard S, Kopp ED. Cut and paste: a no suture, small incision approach to pterygium surgery. Br J Ophthalmol 2004;88(7):911-4.

[8] Rangu RV, Wanjari A, Akhade N. Study of Sutureless and glue free conjunctival autograft. International Journal of Recent Trends in Science and Technology 2014;10(3):480-2. 
[9] Morya AK, Thakur AS, Khan SR. Suture less and glue less limbal conjuctival auto grafting in pterygium surgery. Sch J App Med Sci 2015;3(5D):2033-7.

[10] Kulthe SB, Bhosale AP, Patil PU, et al. Is the surgical technique of a sutureless and glue free conjunctivolimbal auto graft after pterygium excision complications free? Med J DY Patil Univ 2015;8(3):308-12.

[11] Malik KP, Goel R, Gupta A, et al. Efficacy of suture less and glue free limbal conjuctival autograft for primary pterygium surgery. Nepal J Ophthamol 2012;4(2): 230-5.

[12] Rathi G, Sadhu J, Joshiyara P, et al. Pterygium surgery: suture less glue less conjunctival auto grafting. Int J Res Med 2015;4(1):125-8.

[13] Moran DJ, Hollows FC. Pterygium and ultraviolet radiation: a positive correlation. $\mathrm{Br} \mathrm{J}$ Ophthalmol 1984;68(5):343-6.
[14] de Wit D, Athanasiadis I, Sharma A, et al. Sutureless and glue-free conjunctival autograft in pterygium surgery: a case series. Eye 2010;24(9):1474-7.

[15] Elwan SAM. Comparison between suture less and glue free verses sutured limbal conjuctival autograft in primary pterygium surgery. Saudi Journal of Ophthalmology 2014;28(4):292-8.

[16] Sangole AM, Kose DA. A comparative study between surgical outcome of patients own blood vs 10-0 nylon for conjuctival autografting in pterygium excision. J Evid based Med Health 2016;3(34):1621-6.

[17] Singh PK, Singh S, Vyas C, et al. Conjunctival autografting without fibrin glue or sutures for pterygium surgery. Cornea 2013;32(1):104-7.

[18] Sharma A, Raj H, Gupta A, et al. Sutureless and glue free verses sutures for limbal conjuctival autografting in primary pterygium surgery. J Clin Diagn Res 2015;9(11):NC06-9. 